\title{
Going through the labyrinth: the political economy of Argentina's abandonment of the gold standard (1929-1933)
}

\author{
Pablo Gerchunoff and José Luis Machinea
}

ABSTRACT

This article is the short but crucial history of four years of transition in a monetary and exchange-rate regime that culminated in 1933 with the final abandonment of the gold standard in Argentina. That process involved decisions made at critical junctures at which the government authorities had little time to deliberate and against which they had no analytical arsenal, no technical certainties and few political convictions. The objective of this study is to analyse those "decisions" at seven milestone moments, from the external shock of 1929 to the submission to Congress of a bill for the creation of the central bank and a currency control regime characterized by multiple exchange rates. The new regime that this reordering of the Argentine economy implied would remain in place, in one form or another, for at least a quarter of a century. Argentina. pgerchunoff@utdt.edu

José Luis Machinea is a professor at the Department of Economics, Torcuato Di Tella University, Buenos Aires, Argentina. joselmachi@gmail.com 


\section{I}

\section{Introduction}

This is not a comprehensive history of the 1930 s —of economic policy regarding State functions and the production apparatus - or of the resulting structural transformations so often emphasised in the literature. Rather, it is a brief but crucial history of a transition in a monetary and exchange-rate regime that, at its final stage, paved the way for those transformations. Its focus is therefore not on variables of the real economy, but on the tree of laboratory decisions that led to the abandonment of the gold standard in Argentina. The key word in this article is "decisions", referring to critical junctures at which the government had little time of reflect and lacked an analytical arsenal, technical certainties and political convictions. The four years from December 1929 to November 1933 - the period examined in this article - found the Argentine authorities almost permanently mired in uncertainty and ambiguity, except as regards one point: fiscal discipline had to act as a macroeconomic anchor, even if everything else was in question. It therefore follows that the decisionmaking was not a linear process from the gold standard to fiat money, but instead progressed by fits and starts characterized by contradictions and confusion. The gold standard, although not always enforced, had for decades been an unmoveable regulatory reference point and abandoning it was not easy. At times, the severity of the crisis that began in 1929 pushed in the direction of change; at others, the determination (rather than the rational conviction) to see the problems as temporary and to believe that "normalcy" would eventually return reverted that progress. Thus, years later, Raúl Prebisch wrote: "In 1931 we never lost the belief that recovery was around the corner. That was the phrase used across the world: 'around the corner'" (Magariños, 1991).

The title of this article points to its central thesis: macroeconomic policy was traversing a labyrinth. Metaphorically, the entrance to the labyrinth is the past, the not always comfortable but ultimately accepted primacy of the gold standard; the exit is the future: fiat money and the irreversible - and at first distrustedaccommodation to a new global economic reality and new social demands. Historians understand, however, that "entrance" and "exit" are simplistic terms. As events progress, the protagonists do not realize they are entering a labyrinth; neither are they aware that an exit exists and, if they are, they might well be convinced that the entrance is the exit: in other words, that the way out is to return to the gold standard. That was not the case, but it could have been: for the protagonists, one of the possible paths of history is to go back.

Then come the milestones inside the labyrinth; that is, the sequence of critical junctures that occurred over those four years. Section II provides a summary of the economic collapse of the late 1920s and early 1930s. Section III deals with Hipólito Yrigoyen's early decision to suspend the operations of the currency board in December 1929, and the repercussions of that decision for the nominal exchange rate. Section IV analyses the national and international situation in April 1931, the deepening crisis and the innovative response of rediscounting commercial paper through the currency board, thereby foreshadowing one of the functions of a central bank. Section V describes how, in October 1931, following the devaluation of the pound sterling, the Argentine government was alarmed by its own currency depreciation - fuelled by the size of its external imbalance and facilitated by the rediscounting policy - and implemented the first currency control mechanism of the twentieth century to prevent an excessive drop in the peso's value. Section VI examines the surprising combination of currency controls and a return to convertibility under the gold standard that emerged when the authorities pegged the peso to the United States dollar and the French franc in December 1931. That return to traditional policies involved one additional step, which is studied in section VII: when the price of gold rose against the dollar in mid-April 1933, the Argentine government -weathering deflationary pressures - kept the peso tied to the franc, the last of the major world currencies to maintain a fixed gold conversion rate. That, of course, did not last long and, as described in section VIII, in November 1933 the fits and starts came to an end: Argentina emerged from the labyrinth, its currency was devalued, the currency control regime was amended with the introduction of multiple exchange rates and a bill was presented to Congress for the creation of a central bank charged with issuing fiat money. A new regime was born, which would remain in place for at least a quarter of a century. 


\section{II}

\section{The external shock: the deepest peace-time crash in history}

The unexpected and severe shock with which this story opens began early and affected the main raw-material producing countries in the temperate zones: Australia, Canada and New Zealand. When, in mid-1928, the United States Federal Reserve raised interest rates to quell what appeared to be an unsustainable domestic economic boom, there were two interconnected repercussions that, with time, would become well known and recurrent: capital began to emigrate northwards and international food prices began to fall, as had already happened —almost as a rehearsal of later events - during the counter-inflationary adjustment of 1920-1921. Fortune also conspired against Argentina for climatological reasons: the prospects of very poor harvests in 1930 accelerated capital flight and sowed the seeds of an uncertainty that had not been felt since the outbreak of the Great War. It was therefore no surprise that when the cables reporting panic on Wall Street began to arrive in late October 1929, the Argentine authorities and specialists were already alert, or at least not completely unprepared for the onslaught. This was not an unsuspected bolt of lightning on a sunny day. They were unsure how long it would last - the general expectation was that it would be short-lived - but it was clear that a storm had arrived.
And so they entered the labyrinth. According to estimates made in this article ${ }^{1}$ and shown on table 1 , between 1929 and 1932 (the year that reported the decade's lowest levels) the prices of Argentine exports fell by $60 \%$, more than those of Brazil, Chile, Mexico and Colombia and slightly less than those of Australia. Table 2 shows how, over the same period, the terms of trade fell by $35 \%$, a drop almost the same as that reported by Australia. For the analytical strategy used in this study, what happened between the start of the process and its end is not necessarily the most important aspect, because the decisions in the labyrinth were taken at critical junctures when what was going to happen next was unknown. It should therefore be noted that neither the fall in export prices nor the fall in the terms of trade were reverted until 1933. The irony of the story was that the situation was worsening at the same time that, in line with a memory of an economic world that was benign for Argentina, the expectations were for a relatively swift return to the previous "normalcy." The past weighed heavy.

\footnotetext{
${ }^{1}$ This article makes use of export prices, import prices and, consequently, terms of trade that differ from previous studies (Gerchunoff and Machinea, 2015).
}

TABLE 1

Average export prices, 1928 to 1938

(Index: $1929=100$, prices in dollars)

\begin{tabular}{lcccccc}
\hline Year & Argentina & Brazil & Chile & Mexico & Colombia & Australia \\
\hline 1928 & 109.8 & 106.5 & 103.3 & 100.0 & 113.6 & 111.5 \\
1929 & 100.0 & 100.0 & 100.0 & 100.0 & 100.0 & 100.0 \\
1930 & 77.8 & 64.5 & 88.3 & 88.2 & 78.4 & 78.8 \\
1931 & 46.7 & 45.2 & 60.0 & 57.6 & 69.3 & 51.9 \\
1932 & 39.9 & 48.4 & 41.7 & 56.5 & 54.5 & 36.5 \\
1933 & 45.8 & 48.4 & 35.0 & 61.2 & 37.5 & 40.4 \\
1934 & 52.7 & 58.1 & 30.0 & 77.6 & 37.5 & 63.5 \\
1935 & 52.9 & 48.4 & 30.0 & 74.1 & 30.7 & 50.0 \\
1936 & 63.3 & 54.8 & 35.0 & 72.9 & 30.7 & 63.5 \\
1937 & 77.7 & 61.3 & 41.7 & 77.6 & 34.1 & 76.9 \\
1938 & 70.1 & 41.9 & 31.7 & 56.5 & 30.7 & 69.2 \\
\hline
\end{tabular}

Source: Department of Statistics and Censuses, Anuario del Comercio Exterior de la República Argentina, Buenos Aires, various years; Economic Commission for Latin America and the Caribbean (eClac), "Relación de precios de intercambio 1928-1976", Santiago, 1977, unpublished. 
TABLE 2

Terms of trade, 1928 to 1938

(Index: $1929=100)$

\begin{tabular}{lcccccc}
\hline Year & Argentina & Brazil & Chile & Mexico & Colombia & Australia \\
\hline 1928 & 107.4 & 100.4 & 111.3 & 102.4 & 115.5 & 106.2 \\
1929 & 100.0 & 100.0 & 100.0 & 100.0 & 100.0 & 100.0 \\
1930 & 89.1 & 64.5 & 95.1 & 90.4 & 73.7 & 80.2 \\
1931 & 67.5 & 59.6 & 67.2 & 73.4 & 84.0 & 63.6 \\
1932 & 65.8 & 72.6 & 54.3 & 81.8 & 73.1 & 64.5 \\
1933 & 66.2 & 66.5 & 61.3 & 85.6 & 63.9 & 65.5 \\
1934 & 68.4 & 71.0 & 57.9 & 98.8 & 81.5 & 86.5 \\
1935 & 72.2 & 63.9 & 62.2 & 94.3 & 64.4 & 73.2 \\
1936 & 93.9 & 72.4 & 70.0 & 90.1 & 64.4 & 92.9 \\
1937 & 100.7 & 67.4 & 75.3 & 90.6 & 67.1 & 107.3 \\
1938 & 90.7 & 49.4 & 53.7 & 69.8 & 60.4 & 92.3 \\
\hline
\end{tabular}

Source: Department of Statistics and Censuses, Anuario del Comercio Exterior de la República Argentina, Buenos Aires, various years; Economic Commission for Latin America and the Caribbean (ECLAC), "Relación de precios de intercambio 1928-1976", Santiago, 1977, unpublished.

At the same time, the bad news was not restricted to prices. With each passing day, the developing crisis revealed that the rules of the game and the economic policy practices that had more or less prevailed up to 1929 were being questioned: not so much within official discourse as yet, but certainly in the day-to-day decisions of the authorities. International trade contracted because of the recessionary trend, but also because of public policy decisions that, urbi et orbi, directly affected it: widespread protectionist reactions, competitive devaluations and a growing trend towards bilateralism. The most notable indicators of that reorientation were the Smoot-Hawley tariff, adopted by the United States Congress in June 1930, and the Abnormal Importations Act, passed by the United Kingdom in November 1931. The costs were not divided equally among nations. Table 3 shows how Argentina was among the countries worst affected: the tariff hikes fell more heavily on foodstuffs than on manufactured goods and, if there was one characteristic that distinguished Argentina, it was that its enormous gains in market shares had made the country the world's leading food exporter (see figure 1). Although it was not yet entirely clear, that position, which had been 60 years in the making, was now to be lost.

TABLE 3

Increased protectionism, 1927 to 1931

(Import tariffs in percentages)

\begin{tabular}{|c|c|c|c|c|}
\hline \multirow{2}{*}{ Country } & \multicolumn{2}{|c|}{ Foodstuffs } & \multicolumn{2}{|c|}{ Manufactures } \\
\hline & 1927 & 1931 & 1927 & 1931 \\
\hline Austria & 17 & 60 & 21 & 28 \\
\hline Belgium & 12 & 24 & 12 & 13 \\
\hline Bulgaria & 79 & 133 & 75 & 90 \\
\hline Czechoslovakia & 36 & 84 & 75 & 90 \\
\hline Finland & 58 & 102 & 18 & 23 \\
\hline France & 19 & 53 & 26 & 29 \\
\hline Germany & 27 & 83 & 19 & 18 \\
\hline Hungary & 32 & 60 & 32 & 43 \\
\hline Italy & 25 & 66 & 28 & 42 \\
\hline Romania & 46 & 88 & 49 & 55 \\
\hline Spain & 45 & 81 & 63 & 76 \\
\hline Switzerland & 22 & 42 & 18 & 22 \\
\hline Yugoslavia & 44 & 75 & 28 & 33 \\
\hline
\end{tabular}

Source: Prepared by the authors, on the basis of Ronald Findlay and Kevin O'Rourke, Power and Plenty: Trade, War and the World Economy in the Second Millennium, Princeton, Princeton University Press, 2007. 


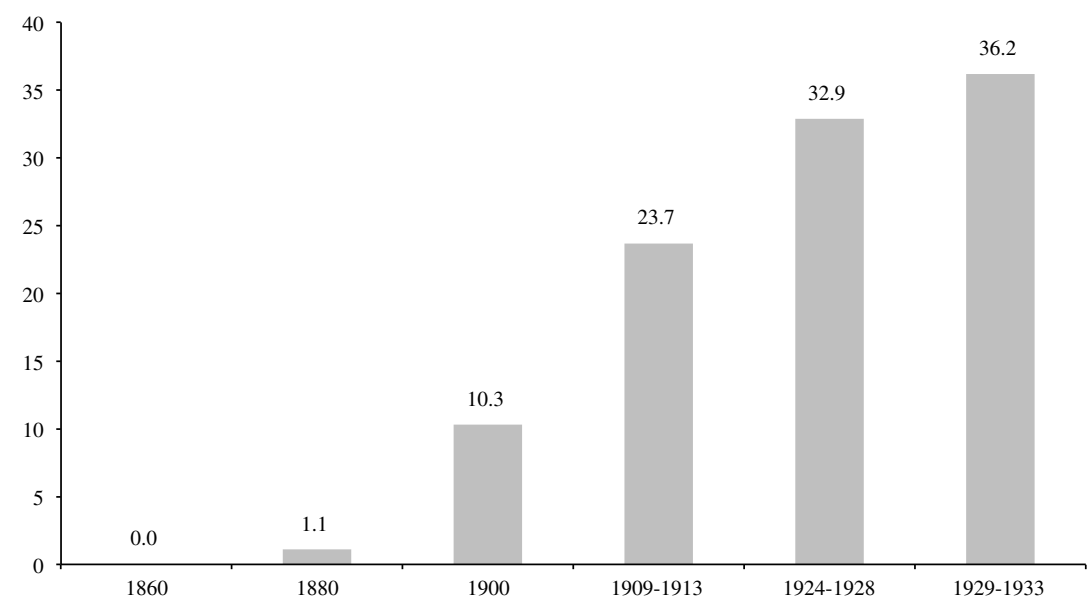

Source: John Hanson, Trade in Transition: Exports from the Third World, 1840-1900, New York, Academic Press, 1980; and Lois B. Bacon and Friedrich C. Schloemmer, World Trade in Agricultural Products. Its Growth, its Crisis and the New Trade Policies, Rome, International Agricultural Institute, 1940.

Note: Includes the following products: wheat, maize, linseed, meat, hides and wool.

\section{III}

\section{Yrigoyen's swift reaction: suspension of convertibility and currency depreciation (December 1929 to April 1931)}

What does a politically weakened government do when faced with adversity and when, at the same time, it is not sure that those adverse conditions will last for long? The answer is not obvious. Indeed, the bias might lean towards inaction. As noted in the Introduction, the players were not necessarily aware that they had entered a labyrinth and, consequently, they might have believed that the free adjustment of the market would lead them to calmer, more familiar waters. However, Hipólito Yrigoyen was fast to make a decision: in December 1929, he signed a decree suspending the currency board. Was that decision a watershed for the economic regime? The answer must be no, for one reason: in 1876, in 1886 and in 1914, internal and external turmoil had forced the adoption of similar measures, moving the country away from the gold standard rule, and in those three instances it had returned to a new version of the monetary system that enjoyed almost unanimous approval. So, the question is: why was that decision made? In this case, the answer is paradoxical. Yrigoyen was no critic of the monetary institutions of the ninetieth century, but at that juncture, those institutions were causing him problems and he chose to temporarily suspend their adjustment mechanism: more specifically, the loss of international reserves was automatically reducing the money supply and imposing harmful recessionary pressure across the board, but most particularly on the undisputed leader of an incipient democratic experiment.

Yrigoyen's decision was wiser than he could ever have suspected, from that time until his death in July 
1933. ${ }^{2}$ The early closing of its currency board left Argentina at the top of the world ranking in terms of per capita gold reserves, disconnected its cash supply from the fluctuations in the external sector and allowed for the nominal devaluation of the currency, which was the correct remedy in light of falling export prices and dwindling sources of external funding. And not only was it the correct remedy, one that almost all the world's countries would adopt shortly after, but also his timing could not have been better. ${ }^{3}$ Even so, the measure was not entirely original. The other temperate-zone food producers reacted similarly and almost simultaneously: Uruguay suspended its currency board's operations shortly before Argentina; in December 1928, Canada introduced various restrictions that ultimately meant abandoning convertibility; ${ }^{4}$ shortly before, Australia had urged its banks to form a cartel that would supply limited amounts of foreign currency. The dynamics of the events culminated with a de facto abandonment of convertibility in December 1929 (Eichengreen, 1995).

Suspending convertibility meant the de facto adoption of a floating exchange rate regime. Given the imbalance in the balance-of-payments current account and the growing obstacles to funding on international capital market, the emerging unknown was the magnitude of the currency's depreciation. Considering the severity of the shock, in a context of scant depletion of reserves and without quantitative restrictions on imports, the $25 \%$ devaluation that occurred between November 1929 and December 1930 was surprisingly moderate (see figure 2 ). ${ }^{5}$

\footnotetext{
${ }^{2}$ For a detailed analysis of Yrigoyen's decision - albeit one that, from the point of view of this article, over-credits him with lucidity regarding the problems of the gold standard - see Campos (2005).

${ }^{3}$ Unlike Argentina, most of the countries that abandoned convertibility over the ensuing months and years did so when their reserves were nearing depletion.

4 In December 1928, the Canadian government increased the cost of conversion by changing the gold delivery location to Ottawa and, shortly afterwards, distributing British instead of United States coins. In March, the commercial banks agreed with the government to halt all further exchanges. However, the Canadian dollar returned to values close to parity during the second half of 1930 . Convertibility would only permanently disappear after the devaluation of sterling in October 1931 (Shearer and Clark, 1984).

5 As a consequence of the fall in export prices and the poor harvest, exports in 1930 were US\$ 397 million lower than in 1929: a drop of $45 \%$. This was partially mitigated by the $12 \%$ drop in the price of imports, which meant saving some US\$ 100 million. In spite of the surplus of US\$ 88 million, the current account deficit was US\$ 159 million in 1929 , which was funded entirely by the drop in international reserves. To maintain 1929's level of activity and import volume in 1930 without losing reserves and maintaining a neutral capital account, the current account had to be balanced, which meant reducing the imbalance by some US\$ 456 million. That figure is the result of adding the fall in export value to the 1929 current account deficit and subtracting the
}

Two factors helped achieve that result, thereby enabling the short-term financing of a portion of the imbalance. First, the government and the railway companies took on short-term loans in the already dwindling international capital market (O'Connell, 1984); and second, many firms were convinced that after a time, the turbulence would cease and the peso would return to parity and, with that argument — erroneously, as events make clear - they delayed the remittance of profits and dividends.

Reality took the opposite path. In early 1931, the global crisis worsened, particularly in the United States. The margin for securing credit on the international markets disappeared and export prices continued to fall faster than import prices, and all this took place in a context of deflation that affected banks' balances. In spite of that, the military regime that had displaced Hipólito Yrigoyen from power and had been ruling since September 1930 decided to reaffirm its commitment to the economic order it had inherited. The decision that made this clear was the announcement that the public debt payments schedule would be respected. That decision has always been perplexing to historians. Why do so when the State's finances were floundering; when all the region's countries —with the exception of Haiti and the Dominican Republic - announced partial or total suspensions of payments between 1931 and 1933 ? There are three possible — and not mutually exclusiveanswers to that question. First, the crisis of 1890, with the default in debt servicing that it brought, had caused a painful (albeit brief) interruption in Argentina's growth and no one was willing to repeat the experience. Second, since that crisis, Argentina had been the "star pupil" in regional terms, and "one of the stars" if seen globally: why squander that reputation merely in order to avoid a sacrifice that was expected to be of limited duration? Finally, the ruling class was not yet paying particular attention to Argentina's Latin American neighbours because they believed their country was in a different league. Australia and Canada, with public debts that had grown between 2.5 and 3.5 times, but with closer ties to the United Kingdom and the United States, respectively,

drop in import value caused by falling prices (US\$ 100 million). Since 1929 imports totalled US\$ 750 million and exports would not react immediately, imports had to fall by $60 \%$, or by around US $\$ 450$ million. A reduction of that magnitude required not only an extraordinary hike in the exchange rate, but also a reduction of absorption. Consequently, without a recession or quantitative restrictions, the devaluation to balance the current account was substantially larger than that seen in the markets. In part, this was because the situation was believed to be only temporary. However, the $18 \%$ drop in exports in 1931 would show that the imbalance was more than a passing phenomenon. 


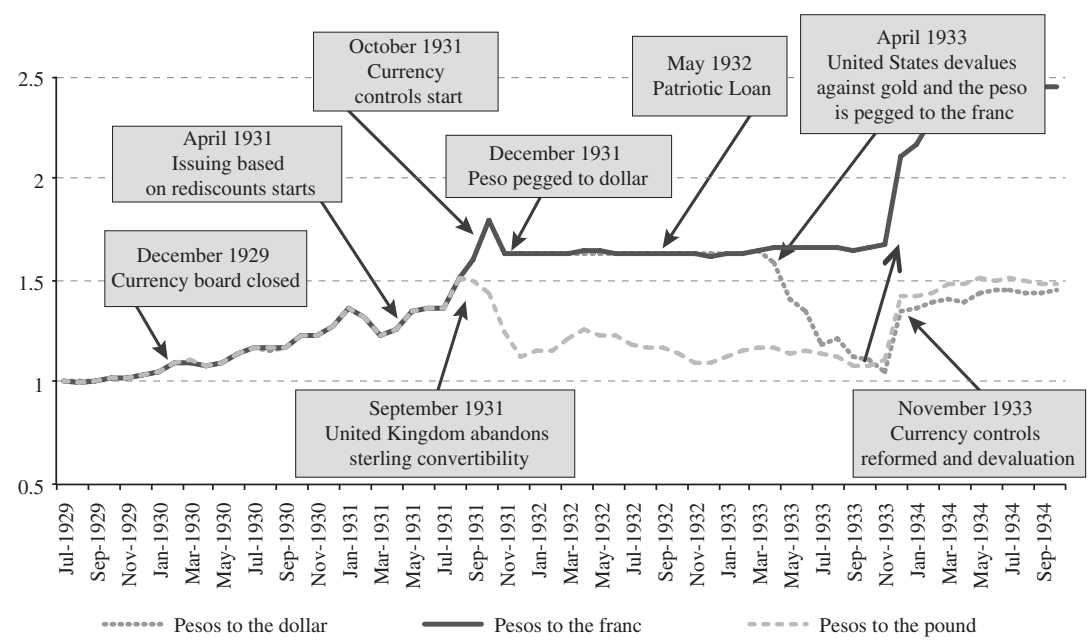

Source: Prepared by the authors, on the basis of data from the Revista de Economía Argentina, various years; National Bureau of Economic Research; and Federal Reserve Bank of Saint Louis.

continued to pay what they owed, at least to their foreign creditors. ${ }^{6}$ Those were the examples to follow.

Above and beyond the potential costs and benefits of José Félix Uriburu's decision regarding the debt, ${ }^{7}$ there is one irrefutable fact that brings us back to the dilemmas of economic policy as the protagonists at the time saw them (that is, without the -impossible- benefits of knowing the future): paying the debt was incompatible with a more or less controlled depreciation of the currency. In the context of a deepening crisis in which foreign borrowing was out of the question, the peso suffered a considerable devaluation in late 1930 and, by midJanuary 1931, its value had fallen by $40 \%$ from its level in November 1929, the time taken as the starting point

6 In the case of Australia, at a time of deep recession and with unemployment at $30 \%$, there was an intense political debate, which ended with a decision not to restructure the foreign debt. Since the funds needed to pay the entire debt did not exist, it was decided that local bond holders would contribute to paying off the overseas creditors. This decision was agreed on with local bond holders in a referendum, the result of which was that $97 \%$ of them agreed to reduce the interest on local bonds by $22 \%$ and to extend the maturity periods by up to 30 years.

7 With the wisdom that comes from history, it would appear that the costs outstripped the benefits, since, among other factors, "good behaviour" did not lead to greater indebtedness: by 1937 the public sector foreign debt had fallen by $35 \%$ from its 1930 level. of the story told in this article. ${ }^{8}$ If the aim was to avoid a similar or greater devaluation and, at the same time, to honour the country's debts, one alternative - in the short term at least - was for payments not to pass through the foreign-exchange market, but instead to use the currency board's gold, which was still in abundant supply thanks to the early abandonment of convertibility. That was the path chosen shortly after José Félix Uriburu assumed the presidency. To this was added the intervention of the Banco Nación, which exported 76 million pesos in gold through direct purchases from the currency board. ${ }^{9}$ Reopening the currency board to pay off the public debt and the Banco Nación's intervention had the combined effect of stabilizing the exchange rate for the space of a few months at a level that represented a depreciation of only 26\% from its November 1929 value.

But that did not last long: the failed attempt to secure an external line of credit in April 1931 prevented the closure of the economic policy circle to which the government aspired. That loan would have allowed the

\footnotetext{
${ }^{8}$ The real-term devaluation of the exchange rate was similar, if the measure of unsold goods is taken as the consumer price index in the United Kingdom and the United States of America, and the cost of living in Argentina.

9 The Banco Nación acted in accordance with the decree of 31 January 1930, which allowed it to rotate its conversion funds by withdrawing gold from the currency board (Prebisch, 1932a).
} 
cancellation of a significant portion of the floating debt and would have done so by more than offsetting the releases of gold drawn down to reduce pressure on the foreign-exchange market. In 1876, Nicolás Avellaneda had dreamed of an external loan that never materialized; in 1890, Carlos Pellegrini had that same dream, and now it was José Félix Uriburu's turn. At times of crisis, it is common for frustrated hopes to be placed on hard-to- materialize lines of credit. In this case, the consequence was a faster rate of depreciation after the first half of $1931 .^{10}$

\footnotetext{
${ }^{10}$ Prebisch (1932a) states — not without exaggeration, in the opinion of the authors of this article- that the attempts to secure an external line of credit had to be abandoned at the last minute because of the uncertainty in financial markets caused by the Radicals' winning the governorship of the province of Buenos Aires on 5 April 1931, only a few months after they had been deposed from the presidency.
}

\section{IV}

\section{The rediscounting policy of the Central Bank:} April 1931

Distributing gold from the currency board in exchange for pesos prevented pressure on the foreign exchange market, but not the contraction of the money supply. This had a dual detrimental effect: economic activity fell, and the health of the financial system - whose reserve levels were, by then, the lowest for a decade- deteriorated. In that context, pressured by adverse circumstances, the authorities decided to abandon monetary orthodoxy or, in the terms used in this narrative, distance themselves from the entrance to the labyrinth. Thus, amidst bitter controversy, as of April 25, 1931, they allowed the rediscounting of commercial paper at the currency board and, consequently, money was injected into the economy. ${ }^{11}$ From this article's point of view, what triggered that measure was the monetarily contractionary impact of servicing the foreign debt. Agustín P. Justo's memoirs suggest something similar by indicating that the banks were authorized to "take documents from their portfolios to the currency board and to swap them for banknotes to replace those that the currency board had received in exchange for the exported gold" (Argentine Republic, 1938). Under the floating exchange rate regime, with the currency board closed, the sole destination for gold exports had been public debt service.

Stating that the monetary contraction associated with servicing the debt was the main factor behind the

\footnotetext{
11 Since the start of the century and, most particularly, since the early 1920s, the Banco Nación had been receiving commercial paper from private banks in rediscounting operations that implied no issuing of currency. In 1929, the Banco Nación's rediscounts accounted for $16 \%$ of its loan portfolio and by 1931 , that figure had risen to $27 \%$; as a result, the currency board had to provide liquidity if the Banco Nación was not to face serious strain.
}

issuing of rediscounts is not to disregard the looming emergency threatening some local banks - and indeed the Banco Nación-. On the contrary, the two were clearly related: with assets already feeling the impact of the recession and deflation, the monetary contraction merely heightened the problem. Within the government, particularly inside the Treasury, there was a growing fear of a financial system collapse similar to the one already under way in the United States. Indeed, 15 years later, Raúl Prebisch would make explicit his interpretation of a measure that foreshadowed the functions of the central bank: "The banking system was on the verge of collapse and we decided - the idea was mine - to revive an old bank rediscounting law that had never been enforced" (Della Paolera and Taylor, 2003, p. 226). ${ }^{12}$ The measure was to some extent preventive. The fall in deposits would reach $11 \%$ by the end of 1931 , but between March and April, when the rediscounts began to operate, they were only down $1.5 \%$ from the corresponding months in 1930. Although those figures appear to support the idea that what triggered the issuance of rediscounts was the monetary absorption associated with servicing the debt, it must be recalled that the financial system was already in trouble before the drop in deposits. In fact, following a Minskian pattern of behaviour - that is, clearly procyclical through increased leverage to take advantage of the boom - the private banks' reserves had fallen in the second half of the 1920s. ${ }^{13}$ At the onset of the crisis, pressure on bank reserves rose for two reasons:

\footnotetext{
12 The rediscounting law referred to by Prebisch was the emergency rediscounting law of August 1914.

${ }^{13}$ Bank reserves fell from $24.8 \%$ in June 1928 to $11.4 \%$ in March 1931.
} 
their inability to recover loans during recession and high real interest rates, and the government's need to place floating debt in the financial institutions because of the drop in tax revenues. ${ }^{14}$ On the other hand, the value of bank reserves is an average of the system, and some information suggests that various private banks were in greater difficulties. In addition, the Banco Nación was facing a harsh liquidity squeeze. As Prebisch said in his dialogue with Pinedo: "I explained the critical situation facing the Banco Nación to him. The Banco Nación had the deposits of the cheque clearing house, it managed the clearing house. The money that the Banco Nación had on hand was less than the money in the clearing house. That indicates how serious the situation was" (Della Paolera and Taylor, 2003, p. 226).

To summarize, this article emphasizes the relationship between servicing the public foreign debt and the money supply as a trigger for rediscounting; however, any discussion regarding the causes would probably be sterile because, in general terms, the dimensions of the crisis in early 1931 were pushing — not necessarily out of conceptual convictions, but certainly because of the emergency conditions - for a more flexible relationship between fiat money and gold reserves. From that perspective, rediscounts were an instrument that assured two objectives: preventing monetary contraction associated with debt servicing, and bailing out certain banks. In addition, during 1931, the rediscounts allowed a contraction of loans $(6.2 \%)$ that was significantly smaller than the drop in deposits $(11.3 \%)$. In any event, a full understanding of the different dynamics followed by loans and deposits requires an additional component. The effect reflects entirely the increase in the Banco Nación's

${ }^{14}$ Loans to the government rose from $10.7 \%$ of total loans in 1926 to $20.5 \%$ in 1931 . loans since, in contrast, the loans of the commercial banks fell more sharply than their deposits. ${ }^{15}$

In analysing the crisis, the policy of rediscounting commercial paper at the currency board and the Banco Nación's countercyclical policy cannot be seen in isolation. Both were mutually necessary if any impact was to be obtained. Some authors, in particular Della Paolera and Taylor (2003), have seen the rediscount policy as a genuine change in the macroeconomic regime: in other words, an exit from the labyrinth. Looking back from the end of the story, it is difficult not to concur: an expansionary monetary policy was emerging as a result of deflationary pressure, and it was doing so in the context of the floating exchange rate introduced by Yrigoyen and continued by Uriburu. What else was needed? Would it not be expected that deflation would be reversed and the economy would be reactivated, albeit after a certain delay? A later section of this article will examine the impact on prices and the topic of reactivation, but here it must be noted that the reactivation did not occur at that time. The main reason it did not happen was that there was no such change in the regime, but only an isolated measure. For there to be a regime change, it must be understood and maintained as such by the protagonists at the time, and that was not what happened. The rediscount policy was another step in the comings and goings of disoriented authorities faced with a transformation that was unfolding before their eyes but that, as happened elsewhere, they failed to understand in full. Prebisch (1932a) explained it in his own way by describing it not as a monetary policy measure, but as an inescapable imposition by the circumstances.

15 As analysed by Salama (2000), the Banco Nación acted countercyclically: it increased reserve requirements to $37 \%$ of deposits in 1928 and then decreased them to $27 \%, 17 \%$ and $15 \%$ in late 1929 , 1930 and 1931, respectively.

\section{V}

\section{A lasting innovation: currency controls and fixed exchange rates (October 1931 to April 1933)}

In September 1931, five months after the rediscount policy was introduced, a storm struck the world: menaced by severe capital flight, the Bank of England, which in 1925 had returned to the gold standard at the previous but now uncomfortable peg, was forced to suspend the convertibility of the pound sterling. This was not a "peripheral case" but a currency that was still competing with the dollar for the privileged position of the world's 
main currency, the symbol of stability since the midnineteenth century (Eichengreen and Flandreau, 2009). In line with the nations of the Commonwealth, with which it shared certain similarities in terms of production patterns and trade flows, Argentina followed the pound's movement and then, as shown on figure 2, let its currency float freely for a few weeks, while the confusion caused by the British decision reigned. The result was a further heavy devaluation with respect to the dollar. By August 1931, the peso had depreciated against the dollar by $46 \%$ compared to its November 1929 level and, by October, by $76 \%$. That figure probably explains why the deflation was less severe than in other countries. Between 1929 and 1932, wholesale prices fell by $10.5 \%$ in Argentina, by $35 \%$ in Italy, by $32 \%$ in the United States, by $31 \%$ in France, by $30 \%$ in Canada, by $29 \%$ in Germany, by $28 \%$ in Australia, and by $25 \%$ in the United Kingdom (League of Nations, 1933).

After that whirlwind movement came the inevitable fear of floating. On 25 September 1931, at the Buenos Aires Stock Exchange, Treasury Minister Enrique Uriburu -who had originally launched the rediscount policyannounced the shift in his own position: "Depreciation and monetary instability are the result of the economic and financial dislocation we have received. Those who call for the emission of currency are a real danger if they are heeded" (Revista de Economía Argentina, 1931). What caused that fear? There were several reasons, but one predominated over the others. As shown in figure 3, the devaluation made it difficult for the Treasury to service the debt, and there was a risk that those payments would become unmanageable. However, even if it was not validating the dynamics acquired by the nominal exchange rate, the government was confirming its idea of meeting its external financial obligations, which led to a new risk emerging: plummeting international reserves amid a spiral of contraction. To neutralize that, the economic authorities adopted an institutional innovation that would remain a part of the country's economic history for almost three decades: currency controls. In their initial manifestation, currency controls were established in October 10, 1931, by means of a decree that aimed at the quantitative administration of the foreign currency available. The order of priorities for access to the foreign-exchange market was the following: (i) external obligations of the national government and of the provincial and municipal governments; (ii) raw materials, fuel and vital consumer goods; (iii) immigrants' remittances and travellers' expenses; (iv) non-essential merchandise, including capital goods, and repatriation of profits and dividends of foreign companies. Two points are worthy of note in this regard: first, the absolute priority given to servicing public debt and, in line with the context of insufficient demand, the absolute lack of priority assigned to capital goods; second, if there was to be a fixed exchange rate and the demand for foreign currency was not totally satisfied, quantitative restrictions would be imposed and, consequently, a parallel market would emerge.

As it happened, for a few weeks currency controls existed alongside the floating exchange rate; accordingly, there was full access to foreign currencies, albeit at rising prices and without a parallel market. The government was counting on the stabilization of the exchange rate as the result of negotiations with the local banks. Those negotiations failed and, as a consequence, the government opted for unilateral stabilization and enforced quantitative restrictions in accordance with the priorities listed above. The way in which it was done, however, made it clear that the government was living in two different worlds. In December 1931, they decided to peg the peso to the dollar and the French franc, the two leading currencies still following the gold standard. An oddity was thus created: currency controls, managed by a Joint Commission, were combined with a fixed exchange rate, but tied to gold through the dollar and the franc (see figure 2). The result was a slight appreciation of the nominal exchange rate and, above all, expectations for the future stability of the peso. Within two months it became clear that the reversion of the deflationary trend had only been temporary; in February 1932, deflation gained momentum and it continued until November 1933 (see figure 4).

This article is not the place for determining whether the recession caused the deflation or whether the deflation caused the recession. What is certain is that the effects of the Great Depression caused recession and deflation and, as Keynes would show shortly afterwards, they also weakened the effectiveness of monetary policy. This was compounded by the effect of the deflation on debt and, in general, on demand (à la Fisher). Both effects worsened the recession and the deflation and further confused the authorities because, among other repercussions, tax revenues began to suffer the depressive impact more intensely. The difficulties that prevented reason from prevailing were numerous. The internal coherence of that forced monetary and exchange-rate architecture was not evident at first sight. Argentina was a de facto member of the gold bloc, but for that decision to be sustainable without it consuming its reserves - which were so healthy in 1929 - it had to impose quantitative restrictions on the sale of foreign currency according to pre-established 
FIGURE 3

Interest on the public debt

(Percentages)

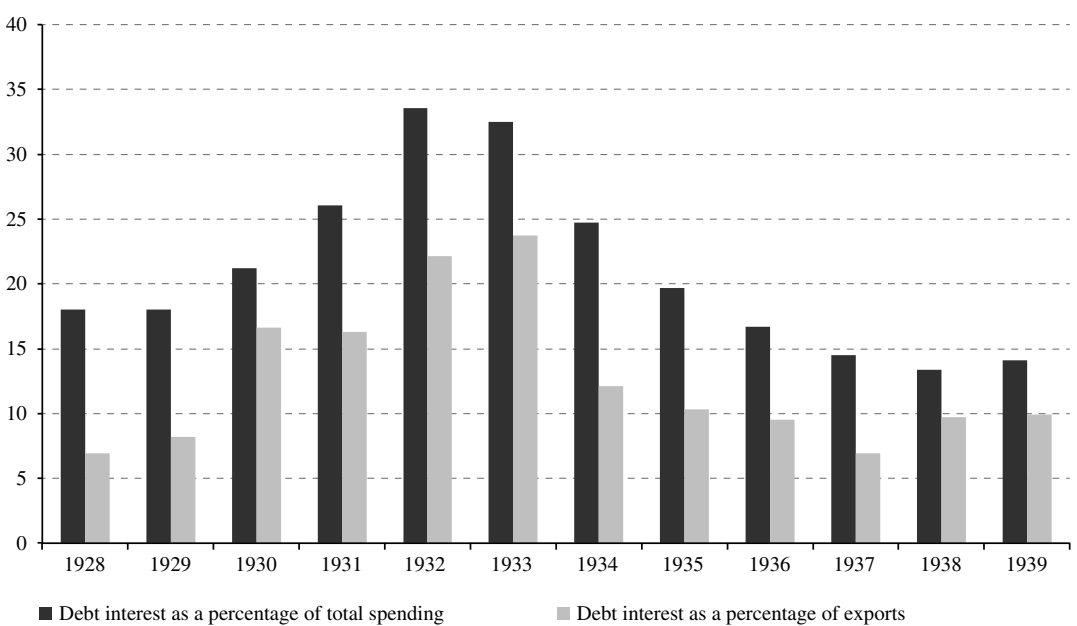

Source: National Geographic Committee, Anuario geográfico argentino, Buenos Aires, 1942.

FIGURE 4

Devaluation and wholesale prices

(Index: November $1929=100)$

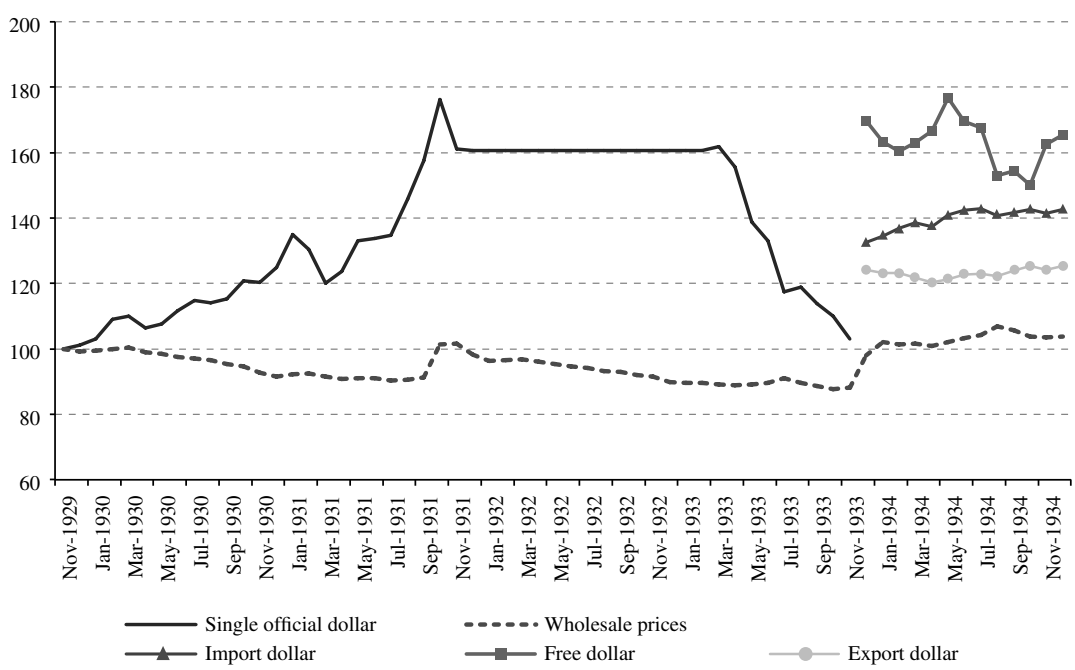

Source: Prepared by the authors, on the basis of Revista de Economía Argentina, various years; and Vicente Vásquez-Presedo, Estadísticas históricas argentinas II (comparadas), Buenos Aires, Ediciones Macchi, 1976.

priorities. Austria was doing something similar at almost the same time as Argentina, and Germany, Hungary and Italy would ultimately do so as well. What invisible thread bound Argentina to those nations ravaged by war and internal turbulence? The crisis itself, the sensation of the labyrinth. In Argentina's case, what had happened to the currency board's rediscounting policy, that spurt of currency emission that seemed to flag a regime change? It is tempting to say that its appearance of solidity had vanished into thin air. However, the depression was too severe for similar experiments not to be attempted, albeit at smaller scales. In that regard, a reference to an example 
from the fiscal regime is elucidating. Pressed for funding, which was strictly rationed in the capital markets, the incoming administration of President Agustín P. Justo attempted, in mid-1932, to place the so-called "Patriotic Loan" on the local market for the amount of 305 million pesos. Less than $50 \%$ (135 million) was taken up by the private sector, the commercial banks included. Paper placed with the currency board made up the remaining 170 million, which meant their counterpart was the issuing of money. Once again, the question arises: a further step towards fiat money or merely a response to the emergency?

\section{VI}

\section{De facto gold standard: doubling down (April 1933 to November 1933)}

The end of the gold standard's history in Argentina - which will be examined in the next section- was only in part due to the initiative of the national authorities. The currency controls of October 1931 contained a technical error that would bring troublesome consequences for international economic relations and macroeconomic management, and it was only during the negotiations for the Roca-Runciman Pact that the costs of that error became apparent and paved the way for a definitive transformation. The problem was that the currency control regime - the work, inevitably, of non-expertslimited the amount of foreign currency handed over to importers, but not their spending. In other words, the Joint Commission and the Treasury authorities were concerned about the foreign-exchange balance, but not about the trade and current account balances. ${ }^{16}$ Contracts for future payments in foreign currency were entered into, but when payment time arrived it

\footnotetext{
${ }^{16}$ In any case, it was clear that the exchange-rate regime, by creating uncertainty regarding access to foreign currency, compressed the demand for imports.
}

was not always possible to meet those commitments. This led to rising amounts of debt (see table 4), above all with those countries with which Argentina ran a trade surplus, particularly the United Kingdom and Germany. This was compounded by the currency control priorities, under which private companies' profits and dividends were often not repatriated but were instead frozen in pesos in local banks. The dynamics of this debt became potentially explosive, because the currency control mechanism was designed to keep the peso from depreciating and, as argued by the newspaper La Nación, that encouraged imports and discouraged exports. ${ }^{17}$ Under those rules, convergence towards a stable situation was not possible.

\footnotetext{
${ }^{17}$ In connection with the currency controls, in the weeks prior to the November announcements, an editorial in La Nación stated: "Maintaining debt servicing, without attempting to reach any arrangement to reduce it; maintaining the exchange rate, without understanding why imports were being privileged to the detriment of exports; the growing preference given to permits for remittances to pay the public debt: these are, in our view, actions that go against the country's interests" (Revista de Economía Argentina, 1933).
}

Differential between imports and foreign-currency sales

(Millions of pesos)

\begin{tabular}{|c|c|c|c|c|c|c|}
\hline & \multicolumn{3}{|c|}{1932} & \multicolumn{3}{|c|}{1933} \\
\hline & Imports & $\begin{array}{l}\text { Foreign currency } \\
\text { sold }\end{array}$ & Difference & Imports & $\begin{array}{l}\text { Foreign currency } \\
\text { sold }\end{array}$ & Difference \\
\hline Jan-Jun & 404.7 & 406.4 & -1.7 & 430.8 & 388.5 & 42.3 \\
\hline Jul-Dec & 431.6 & 321.1 & 110.5 & 466.3 & 273.8 & 192.5 \\
\hline Total & 836.3 & 727.5 & 108.8 & 897.1 & 662.3 & 234.8 \\
\hline
\end{tabular}

Source: Prepared by the authors, on the basis of República Argentina, Poder Ejecutivo Nacional 1932-1938, vols. 1 and 2, Buenos Aires, 1938. 
That inconsistency was aggravated in mid-1932 by the Ottawa Pact. Once the imperial trade preferences agreed on by the members of the Commonwealth - a long-standing demand of the non-British members- were put in place, exports of Argentine meat to the United Kingdom would be limited, thus benefiting Australia and English and Scottish producers. The authorities immediately called for the decision to be reconsidered and, with that purpose in mind, a delegation led by Vice-President Roca travelled to London. The details of the Roca-Runciman Treaty will not be examined in this article. ${ }^{18}$ In the commercial arena, Argentina sought —and largely obtained — less discriminatory treatment for its meat exports; in turn, the United Kingdom requested —and secured- commercial benefits, such as a differentiated (lower) exchange rate for imports from the British Isles and a reduction of tariffs exclusively for its exports. Argentina thus experienced, at first hand, the harshness of British bilateralism. ${ }^{19}$ No one was more transparent than John Maynard Keynes in explaining this policy that clearly further worsened Argentina's terms of trade: "We want meat and we are willing to pay 110 pounds for it; Argentina wants a car that costs 110 pounds in the United Kingdom and 100 in the United States; the United States does not want meat: it has placed a tariff on it and will not pay more than 50 pounds; Argentina has meat and would happily accept 100 pounds for it rather than not sell it, but it is not willing to accept less than 100; we, who have no dollars, can only buy the meat if we sell the car. Under a system of free trade, the exchange would not take place, because if we pay for the meat with money, at either 100 or 110 pounds, Argentina would spend that money to buy a car in the United States and we would be left insolvent. Some system whereby our purchase of meat depends on Argentina buying our car is the only way the exchange can take place. Otherwise, both the Argentine meat producers and our car manufacturers would be out of a job" (De Paiva Abreu, 1984).

Most of the historiography has focused on an impassioned debate regarding those commercial aspects of the Treaty. Of equal importance, however, were its financial aspects, which arose specifically from the

\footnotetext{
${ }^{18}$ For an assessment of the treaty, officially styled the Convention and Protocol on Commercial Exchange with Great Britain and Northern Ireland, see Fodor and O'Connell (1973).

19 The United States, which had a trading relation with Brazil similar to the United Kingdom's with Argentina, also brought pressure to bear on Brazil to secure certain trading and debt-related benefits. However, in spite of Brazil's refusal to grant those requests, the United States never resorted to specific coercive measures (De Paiva Abreu, 1984).
}

Argentine debt that the shortcomings that the October 1931 currency control regime had created. Thus, in the negotiations the United Kingdom secured corrections to the currency control regime so that the accumulation of debts would not reoccur; it also obtained the repayment of current and future debts at a privileged exchange rate compared to that used for other creditors. ${ }^{20}$ Argentina, for its part, secured the issuing of an "unblocking loan" in sterling at a rate of $4 \%$ to meet its debt obligations. ${ }^{21}$ In addition, the Argentine government also received an amount equal to the amounts used for unblocking as "a loan undersigned by the British investor, having the possibility of increasing it at its entire discretion." Those funds were used to pay off the floating debt and to buy back public debt, as part of an domestic debt restructuring process to be undertaken by the government. Given the irreversible decision to keep up with external obligations, the absence of that loan would not only have caused a greater depreciation of the peso (which at this time they were seeking to avoid), it would also have hindered the lowering of interest rates and consequently the reconversion of domestic debt (Alhadeff, 1985).

While the negotiations between Argentina and the United Kingdom remained under way, with their ups and downs, Franklin D. Roosevelt was sworn in as President of the United States and another 60 days of bank runs and rising demand for gold led to the abandonment of dollar convertibility. In response to that decision, Alberto Hueyo, Argentina's Treasury Minister, reacted with a final gesture of monetary orthodoxy: not only did he peg the peso to the French franc, the last bulwark of the gold standard, he also — and in contrast to what had happened with the depreciation of sterling - prevented the peso from following the dollar. In other words, in spite of the problems of the external sector, he decided to raise the value of the peso against the dollar and against all the currencies that depreciated in tandem with it. There is no easy explanation for this decision, other than the excessive burden of the debt, now increased by the British loans. ${ }^{22}$ But the lack of a convincing explanation does not mean that the minister's convictions were not sincere.

\footnotetext{
${ }^{20}$ As will be seen below, future payments of dividends and interests would be made in full at the official exchange rate, an advantage not available to other countries, the most important of which was the United States.

21 This entailed complex financial engineering. The holders of the blocked funds received government bonds that were bought by the newly founded Argentine Convention Trust, which was in turn funded with bonds placed on the British market.

22 In fact, the subsequent resignation of Alberto Hueyo was on account of his disagreement with Agustín P. Justo's decision to take the loan.
} 
In response to a question by Senator Matías Sánchez Sorondo, Hueyo firmly rejected depreciation: "Alarm and panic can lead to a catastrophe. In these conditions, the government is similar to an engine-driver at high speed who has lost control of his locomotive, and I doubt there is one Argentine with an understanding of our financial history whose hand would not tremble upon signing a devaluation decree, thinking of the chaos that such a measure could cause within a country's economy" (National Congress, 1933).

\section{VII}

\section{Exiting the labyrinth: fiat money and reformed currency controls (November 1933)}

Hueyo's attachment to the gold standard was a fleeting and clearly anachronistic episode. In August the Minister left office and was replaced by Federico Pinedo, the representative of the Independent Socialist Party in the Concordancia following the death of De Tomaso. In November 1933, with Raúl Prebisch's backing, Pinedo announced his Economic Action Plan. In a bid to revert the appreciation of the exchange rate - compared to November 1929, the peso was down a mere $5 \%$ - the authorities implemented a devaluation of around $20 \%$ for traditional exports and around $30 \%$ for imports with currency-exchange permits. ${ }^{23}$ Almost simultaneously came the announcement that a bill was to be sent to Congress for the creation of a mixed-ownership central bank that would be responsible for managing monetary policy. One original feature was that this monetary policy would put in place a new kind of currency controls, seeking to resolve the shortcomings of the model introduced in October 1931 and to satisfy, seven months later, the British demands arising from the Roca-Runciman Treaty.

In early 1934, Pinedo explained the new version of the currency controls, a tool that pursued several objectives: "Our export prospects did not promise the possibility of paying off the foreign-currency debt in the immediate future, since the foreign currency available was not sufficient to cover the current year's needs. The government was therefore facing a dual problem: cancelling that mass of past-due commitments, to prevent them from continuing to pressure the currency market, and preventing the continued accumulation in the future of new unmet commitments" (Revista Económica, 1934).

${ }^{23}$ These are average values of the exchange rate over the three months following the devaluation. The free exchange rate at that time was reporting a devaluation of $59 \%$.
An analysis of table 5 and its interesting implications in this light reveals that under the new regime, there was an official exchange rate and a free one. To award access to cheap foreign exchange (at the official exchange rate), prior permits issued by the Currency Control Commission were distributed. That distribution was neither neutral nor innocent: foreign-currency permits were given, on a priority basis, to importers of goods from countries with which payment arrangements had been signed and which sent profits and dividends to those countries. ${ }^{24}$ With whom had Argentina signed payment arrangements? At that date, with the United Kingdom alone. In 1934, Belgium, Switzerland, the Netherlands and Germany were added to the list, and several other countries joined their number over the ensuing years. In contrast, those countries with which payment arrangements had not been signed (most importantly, the United States) would bring in their merchandise and take out their profits and dividends in accordance with the official exchange rate only after the priority demand (that coming from countries with payment arrangements) had been satisfied. Otherwise, they were forced to make use of the free market, which was by definition more expensive: thus, in the first half of 1934, the free exchange rate was on average more than $20 \%$ above the official exchange rate.

How were payments distributed between the official and free markets when the new regime came into effect? Over 1934 and 1935, around 60\% of imports from countries without payment arrangements entered the country at the official exchange rate and $40 \%$ at the

\footnotetext{
${ }^{24}$ Foreign debt servicing is not included because the Roca-Runciman Treaty clearly stated that payments "in a reasonable amount" were, as had been the case in 1931, the first priority of the currency control regime irrespective of the creditor.
} 
Currency control reforms of November 1933

\begin{tabular}{|c|c|c|}
\hline \multicolumn{3}{|c|}{ Free exchange rate } \\
\hline Foreign currency supply & \multicolumn{2}{|c|}{ Foreign currency demand } \\
\hline Foreign investments & \multicolumn{2}{|c|}{$\begin{array}{l}\text { Partial imports (approximately } 40 \% \text { ) from countries without } \\
\text { payment arrangements }\end{array}$} \\
\hline Exports to neighbouring countries & \multicolumn{2}{|c|}{ Partial remittances to countries without payment arrangements } \\
\hline \multicolumn{3}{|l|}{ Regional crops } \\
\hline \multicolumn{3}{|c|}{ Official exchange rate } \\
\hline Foreign currency supply & Government & Foreign currency demand \\
\hline \multirow[t]{4}{*}{ Traditional exports } & Exchange differential & $\begin{array}{l}\text { Total imports from countries with payment } \\
\text { arrangements }\end{array}$ \\
\hline & & $\begin{array}{l}\text { Total remittances to countries with payment } \\
\text { arrangements }\end{array}$ \\
\hline & & $\begin{array}{l}\text { Partial imports (approximately } 60 \% \text { ) from } \\
\text { countries without payment arrangements }\end{array}$ \\
\hline & & $\begin{array}{l}\text { Partial remittances to countries without } \\
\text { payment arrangements }\end{array}$ \\
\hline
\end{tabular}

Source: Pablo Gerchunoff, "Circulando en el laberinto: la economía argentina entre la depresión y la guerra (1929-1939)", Cuadernos de Trabajo IELAT, No. 10, Alcalá de Henares, University of Alcalá, 2010.

free exchange rate. ${ }^{25}$ In those same years, the United Kingdom received $40.2 \%$ of the total assigned to the official currency market, compared to $33.7 \%$ in 1933 , before the reforms made to the currency control regime. Over time, bilateralism expanded. Several countries with trade deficits with Argentina, including France and Italy, signed trade agreements with a bias towards compensated exchange.

The above paragraphs provide an overview of the British advantages secured in the negotiations of the Roca-Runciman Treaty and enshrined in the design of the new currency control regime. There was, nevertheless, some manoeuvring space for the Argentine authorities to implement their own policies. For example, following the logic of "buying from those who buy from us", the signing of settlement arrangements with several countries over the ensuing years reduced the British advantages

\footnotetext{
25 This is an estimate based on Salera (1941), but the percentages traded on each market would change over time according to the availability of foreign currency. In addition, the percentage of official market authorizations that each country received depended on several factors, including the type of goods being imported. The priority imports were intermediate goods, raw materials and, to a lesser extent, capital goods. For example, Salera indicates that in the case of imports from the United States, the percentages that passed through the official market were $35 \%$ in $1935,46 \%$ in 1936 and $60 \%$ in 1937 , which yields an approximate average of $50 \%$.
}

in relative terms, although they remained in place for the most important competitor, the United States. In addition, an exchange margin was set between currency purchases and sales in the official market; this operated as a tax on traditional exports, with a portion of the revenue assigned to servicing the public debt and another used to support farm prices through the National Grain Board, which was set up for that purpose. The tax on traditional exports restricted the potential expansion of the domestic supply of agricultural products and became a classic element in Argentine economic policy over much of the following 80 years. There are two possible explanations for that decision. First, the conviction that given the international context, it was difficult to sell more on international markets and that attempting to do so would cause lower prices for those products as a result of Argentina's weight in global exports (see figure 1). Second, that greater protection was needed to promote industrial development, a process that with the passage of time appeared to be the only way to sustain access to manufactured goods, given the change in international markets and its impact on export capacities.

In turn, the free exchange rate would apply to nontraditional exports, to exports to neighbouring countries (naturally, with Brazil being the most attractive target) and to a similarly sized proportion of products from the 
economies of the region (upper left-hand quadrant on table 5). This was a more long-term strategy intended to diversify products and export destinations. If it were successful, the country would secure its independence from the British bilateralist impositions. Similarly, when Federico Pinedo returned to the Ministry of the Treasury in 1940, he was very close to reaching a customs union agreement with Brazil; those efforts were frustrated, however, by the mutual distrust and economic nationalism that prevailed between the two countries' militaries. ${ }^{26}$

These innovations in Argentine economic policy - such as the creation of the Central Bank, the introduction of fiat money and the new currency control regime with multiple exchange rates (see figure 5$)^{27}$ - were broadly maintained over the ensuing years. However, their application during the 1930s was distinguished by certain hallmarks from what would come later. The Central Bank pursued a countercyclical monetary policy that would not be repeated, at least not as a systematic

${ }^{26}$ This is a reference to the Treaty of Progressive Free Exchange signed by Argentina and Brazil on November 21, 1941. The project, proposed by Pinedo, gave advantages to heavy industry on the Brazilian side, which was vetoed by the Argentine military. Argentina's neutrality during the World War, in contrast to Brazil's joining the Allies, brought a definitive end to the treaty (Porcile, 1995).

27 Presenting the Central Bank and the currency control regime as innovations only makes sense within the sequence of Argentina's history. Other countries in Europe and Latin America, with their individual variations, had adopted them earlier (Ortiz, 2014). rule. Currency controls, with the main characteristics of the November 1933 regime, would remain in place for almost the entire decade: multiple exchange rates and no quantitative restrictions on imports. This indicates that during those years, there was no parallel currency market. ${ }^{28}$ In light of the falling exchange rate on the free market, in 1935 a tax was created whereby unauthorized imports or transfers would be carried out at an exchange rate with a differential from the official market rate of no less than $20 \%$ (see figure 5). ${ }^{29}$ That change was in line with the privileges granted to the United Kingdom in 1933 and then extended to all the countries with payment arrangements. It was not until 1938 that restrictions were to be placed on imports through the free currency market, and that was the start of another exchange-rate regime that would define much of the following two decades.

Clearly, the gold standard had been confined to the past. The conviction that this was a definitive solution was based on the two pillars of economic policy referred to and briefly described above: the creation of the Central Bank, with goals that were largely incompatible with

\footnotetext{
${ }^{28}$ In contrast, the currency control regime of October 1931 had given rise to a parallel market, known the bolsa negra, with a differential from the official exchange rate of around $40 \%$.

29 The existence of multiple exchange rates triggered the classic mechanism of under-invoicing exports. In 1936, the government decided that exports classified as traditional by the Central Bank's Exchange Commission would be subject to quotas (De León, 2014).
}

FIGURE 5

Multiple exchange rates after November 1933

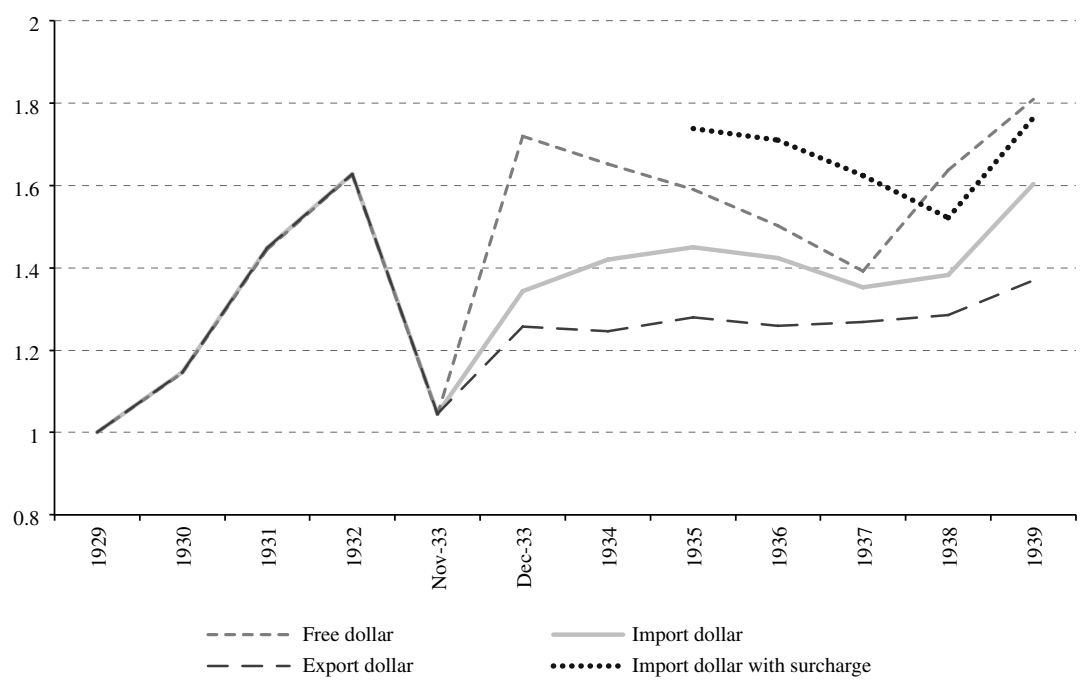

Source: Prepared by the authors, on the basis of Virgil Salera, Exchange Control and the Argentine Market, New York, University of Columbia Press, 1941; and Revista de Estudios Económicos, various issues. 
the gold standard, and the currency control regime with multiple exchange rates. After 1933, the Argentine economy embarked on a period of recovery that, ups and downs notwithstanding, would last the rest of the decade. Did the economic policy innovations of the early 1930s help the economy escape depression and deflation? It appears that they helped, but that they were not the determining factors. The devaluation of the peso encouraged greater import substitution and the resulting industrial growth largely offset the drop in farm prices and, along with the creation of fiat money through the financing of the banks and the Treasury, it prevented higher deflation and a financial crisis. The reduction of the real interest rate associated with the lower deflation and its reversion in late 1933 to positive rates of inflation, together with the refinancing under favourable conditions offered by the Banco Nación and the Banco Hipotecario, were among the factors that encouraged the recovery. In contrast, finding expansive elements in fiscal policy is difficult, at least before 1933, since the reduction of the fiscal deficit in the midst of the recession was 2.5 percentage points of GDP. After 1933, and in a context where external restrictions had ceased to be the main limiting factor on growth, fiscal policy was slightly procyclical and therefore expansionary, but that feature was partially offset by the Central Bank's countercyclical policies in the second half of the decade. ${ }^{30}$ Nevertheless, above and beyond the contributions of economic policy, in the view of this article's authors, the chief factor in explaining the recovery were the positive symptoms that the world economy was beginning to show. The expression of those global changes in Argentina was an increase in the international prices of its export products and the reversion of negative expectations as of the end of $1932 .{ }^{31}$ Something had begun to change irreversibly, and very soon that transformation would make itself apparent to all and pave the way for another change: not macroeconomic this time, but structural.

Economy policy had emerged from the labyrinth, notwithstanding other labyrinths that awaited it in the future.

30 The slight increase in the fiscal deficit as of 1933, in a context of recovering economic activity, means that the structural fiscal deficit was increasing, with the consequent repercussions on aggregate demand.

${ }^{31}$ In August 1932, Prebisch (1932b) conjectured that the still incipient improvements in the financial markets and in some export prices would translate, in the short term, into a general expansion of production.

\section{Bibliography}

Alhadeff, Peter (1985), "Dependencia, historiografía y objeciones al Pacto Roca", Desarrollo Económico, vol. 25, No. 99, Buenos Aires, Institute of Economic and Social Development.

Argentine Republic (1938), Poder Ejecutivo Nacional 1932-1938, vols. 1 and 2, Buenos Aires.

Bacon, Lois B. and Friedrich C. Schloemmer (1940), World Trade in Agricultural Products. Its Growth, its Crisis and the New Trade Policies, Rome, International Agricultural Institute.

Buenos Aires Stock Exchange (various issues), Boletín Oficial de la Bolsa de Comercio, Buenos Aires.

Campos, Martín (2005), "El cierre de la caja de conversión en 1929. Una decisión de política económica", Desarrollo Económico, vol. 44, No. 176, Buenos Aires, Institute of Economic and Social Development.

Central Bank of Argentina (1938), Memoria Anual, Buenos Aires.

Comité Nacional de Geografía (1942), Anuario geográfico argentino, Buenos Aires.

De León, Gonzalo (2014), "Causas y características del control de cambio - Argentina, 1931-1958”, thesis, Torcuato Di Tella University.

De Paiva Abreu, Marcelo (1984), "La Argentina y Brasil en los años treinta. Efectos de la política económica internacional británica y estadounidense", América Latina en los años treinta. El papel de la periferia en la crisis mundial, Rosemary Thorp (comp.), Mexico City, Fondo de Cultura Económica.

Della Paolera, Gerardo and Alan Taylor (2003), Tensando el ancla. La caja de conversión argentina y la búsqueda de la estabilidad macroeconómica, 1880-1935, Buenos Aires, Fondo de Cultura Económica.

ECLAC (Economic Commission for Latin America and the Caribbean) (1977), "Relación de precios de intercambio 1928-1976", Santiago, unpublished.
Eichengreen, Barry (1995), Golden Fetters: the Gold Standard and the Great Depression 1919-1939, New York, Oxford University Press.

Eichengreen, Barry and Jeffrey Sachs (1985), "Exchange rates and economic recovery in the 1930s", The Journal of Economic History, vol. 45, No. 4, Cambridge, Cambridge University Press.

Eichengreen, B. and M. Flandreau (2009), "The rise and fall of the dollar (or when did the dollar replace sterling as the leading reserve currency?)", European Review of Economic History, vol. 13, No. 3, Oxford University Press.

Federal Reserve Bank of Saint Louis [online] http://research.stlouisfed. org/fred2.

Findlay, Ronald and Kevin O'Rourke (2007), Power and Plenty: Trade, War and the World Economy in the Second Millennium, Princeton, Princeton University Press.

Fodor, Jorge and Arturo O'Connell (1973), “La Argentina y la economía atlántica en la primera mitad del siglo XX", Desarrollo Económico, vol. 13, No. 49, Buenos Aires, Institute of Economic and Social Development.

Gerchunoff, Pablo (2010), "Circulando en el laberinto: la economía argentina entre la depresión y la guerra (1929-1939)", Cuadernos de Trabajo IELAT, No. 10, Alcalá de Henares, University of Alcalá.

Gerchunoff, Pablo and José Luis Machinea (2015), "Reestimación de los términos de intercambio de la Argentina durante la década de 1930", unpublished.

Hanson, John (1980), Trade in Transition: Exports from the Third World, 1840-1900, New York, Academic Press.

League of Nations (1933), Statistical Yearbook 1932-1933, Geneva.

Magariños, Mateo (1991), Diálogos con Raúl Prebisch, Mexico City, Fondo de Cultura Económica.

National Congress (1933), Diario de sesiones de la Cámara de Senadores, Buenos Aires. 
O'Connell, Arturo (1984), "La Argentina en la depresión: los problemas de una economía abierta", América Latina en los años treinta. El papel de la periferia en la crisis mundial, Rosemary Thorp (comp.), Mexico City, Fondo de Cultura Económica.

Ortiz, Javier (2014), "Los bancos centrales en América Latina", Historia de las Instituciones Monetarias Argentinas, Roberto Cortes Conde, Laura D’Amato and Javier Ortiz Batalla (eds.), Temas Grupo Editorial.

Prebisch, Raúl (1932a), "La acción de emergencia en el problema monetario", Revista Económica, vol. 5, No. 2, Buenos Aires.

(1932b), "El momento presente de la crisis internacional", Revista Económica, vol. 5, No. 7, Buenos Aires.

Porcile, Gabriel (1995), "The challenge of cooperation: Argentina and Brazil, 1939-1955", Journal of Latin American Studies, vol. 27, No. 1, Cambridge, Cambridge University Press.
Revista de Economía Argentina (1929-1934), Buenos Aires. Revista de Estudios Económicos (various issues), Buenos Aires. Revista Económica (1934), Buenos Aires.

Salama, Elías (2000), "La Argentina y el abandono del patrón oro", Documento de Trabajo, No. 28, Faculty of Economic Sciences, Universidad Nacional de La Plata.

Salera, Virgil (1941), Exchange Control and the Argentine Market, New York, University of Columbia Press.

Shearer, Ronald and Carolyn Clark (1984), "Canada and the interwar gold standard, 1920-35: monetary policy without a central bank", A Retrospective on the Classical Gold Standard, 18211931, Michael Bordo and Anna Schwartz (ed.), Chicago, The University of Chicago Press.

Vásquez-Presedo, Vicente (1976), Estadísticas históricas argentinas II (comparadas), Buenos Aires, Ediciones Macchi.

Wells, H.G. (1933), "The Shape of Things to Come", unpublished. 